\title{
The Birth of a Noble Tea Country: on The Geography of Colonial Capital and The Origins of Indian Tea
}

\begin{abstract}
ANDREW B. LIU
Abstract This paper looks at the origins of the British tea industry of India from the standpoint of colonial and semicolonial involvement in, respectively, British India and Qing China. The imposition of the tea industry in Assam was integrally tied to the wars in East Asia fought in order to open markets for the movement of opium and other commodities. British officials championed both policies in the name of modern economic progress, liberalizing trade with the Qing and establishing a productive industry in Assam. The agricultural science of political economy aimed to extract the value of various objects which could then be united in a land hitherto considered a wasteland. Plants, soil and labor were each viewed as isolatable things whose values were objective and calculable. Such static representation, however, was already belied by the dynamic process of gathering and transporting these "things" across the vast and unevenly developed regions of Asia, ultimately valorizing them as a breakfast drink commodity enjoyed worldwide. The origins of the Assam tea plantations, mirroring developments elsewhere, relied upon spatioeconomic connections that force us to reevaluate how the specific histories of British India, Qing China and Southeast Asia are inseparably linked.
\end{abstract}

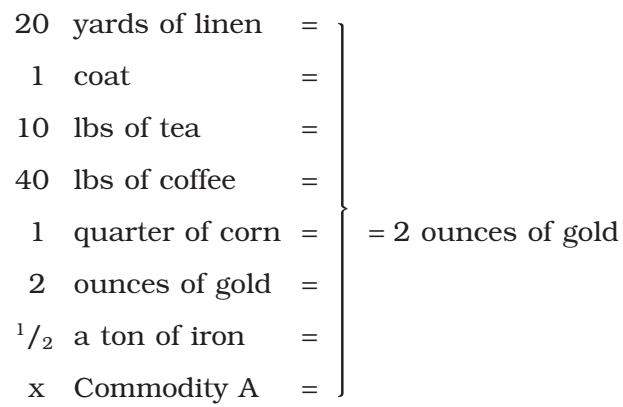

Karl Marx, Capital, Volume one (1867). ${ }^{1}$ 
The first modern, capital-intensive tea plantation in India was but one result of the wide-ranging economic circuits encompassing regions scattered throughout Asia and Europe, which, among other developments, spurred profound transformations in northeast India and the southern coasts of Qing China. It was during the early nineteenth-century decades of nascent British rule in the region of Assam when the following were first established: monetization, land privatization, wage labor, and great investment in transportation to the capital city Calcutta. In brief, a remarkably dense sequence of events over several decades changed areas of Assam from a region devastated by civil wars into a world-class agricultural industry which continues in full capacity today. Meantime, Indian tea owed much of its origins to the synchronous travel of north Indian opium into Qing China, via Canton. For Rebecca Karl, opium holds a "metonymic role [in] . . the history of global commodities in China ... that brought modernity and its related crises to China." Such history could be read as "a crisis of opium ... as the marker of global capitalism in its imperialist colonizing form." ${ }^{2}$ Undeniably, the momentous changes unfolding simultaneously in both regions, and the corresponding movements of particular commodities, were not unrelated to one another. The point here is simply that Indian opium in China and Chinese tea in India need to be thought together, not only because they crossed paths but also because they were central to the historical development of new economic forms taking shape in their respective locales. ${ }^{3}$

In this essay, I want to suggest that one cannot think about British Indian history at this moment without also thinking about British colonial involvement in Ging China. ${ }^{4}$ Besides perhaps the opium trade, the establishment of the Indian tea plantation is the starkest proof of this thesis. My specific focus will be the process of import substitution wherein the British Assam Company, and its government predecessor the Tea Committee, appropriated the tea plant Camellia Sinensis from southern China and cultivated it in Assam during the 1830 s and forties, a complex process which involved gathering tea seeds, plants and laborers from southern China, Southeast Asia and northern India in order to catalyze Indian tea production. Like other plantations around the world, Indian tea gardens relied upon cheap migrant labor settled on the land as well as a large cooperative infrastructure modeled upon the factory systems of urban production. Such gardens were also notable, however, insofar as British growers depended upon Chinese teamakers to learn the secret of growing and preparing the teaplant. The conditions which made the tea plantations a viable project - the overseas market for tea sold by the British, the system 
of inland transport by Chinese farmers, the institutions of exchange at Canton - could be seen as a consequence of overseas trade as much as the byproduct of foreign occupation and land appropriation. This aspect of the Assam plantations' history provides a strong counter-example to prior scholarship which often forgets the deep interdependence between projects of British colonialism throughout Asia, as though they were only marginally related to one another.

Simply put, Assam's development, and the attendant histories of tea and opium, were made possible by the spatial integration of capitalism in Asia. For David Harvey, spatial integration is defined as "the linking of commodity production in different locations through exchange," which has generated a remarkable "historical geography of capitalism," wherein "[p]eoples of the utmost diversity of historical experience... have been welded ... into a complex unity under the international division of labor." ${ }^{5}$ The contemporaries of nineteenth century colonialism were well aware of these circuits, which presented geography less in terms of physical or statist divisions but rather through economic activity. The logic manifest itself clearly in the map of Robert Fortune, a British traveler sent throughout the Chinese countryside to gather tea seeds and mail them to Calcutta (see figure one). Simultaneously bearing in mind Fortune's map while trying to understand the development of tea plantations in Assam is, I believe, the most

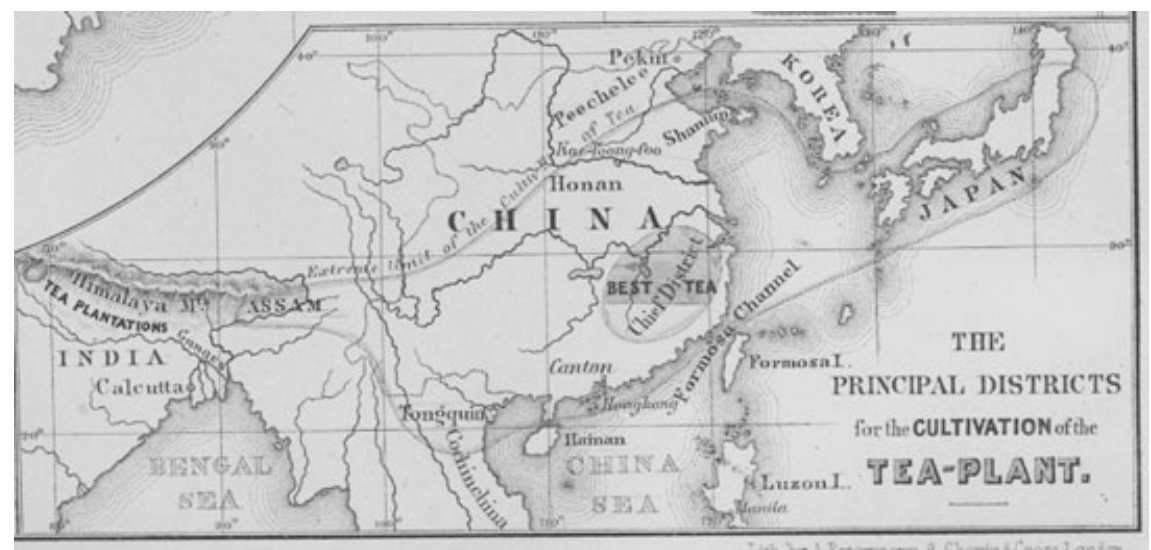

Figure 1: An 1853 map produced by the British explorer Robert Fortune containing some key locations in the commodity flows of colonial Asia. The territory of Assam is located in the west, with the tea plantations labeled near the western edge. The highlighted area labeled "Best Tea" is the Fujian province's Wuyi Mountain tea country. Canton is the main trading port through which opium was purchased by British country traders. ${ }^{7}$ 
helpful approach for comprehending how the economic and social transformation of a local space was made possible by the transfer of technology and knowledge through global circuits of exchange. ${ }^{6}$

However, these locales were not integrated in only purely materialist terms. Assam and Canton were also caught inside bureaucratic debates over political economy and the role of the British state in regulating commerce. In other words, ideas traveled, too. The most important were the physiocratic notion that economic value was locatable in land, expressed in the 1793 Permanent Settlement of Bengal, as well as the subsequent nineteenthcentury ultra-rationalizations of agriculture and trade that inaugurated a discourse of economic science animating colonial enterprise within and beyond the South Asian context. The purveyors of science represented their own activity largely in terms of organizing, manipulating and improving static things they encountered overseas, such as plants, animals, people. The tremendously dynamic and overlapping activity that made colonialism possible was often at odds with the bureaucratic rhetoric of discovery and observation.

I will more closely examine the inaugural years of tea experimentation in following sections, but first I will explicate some details to clarify their context and background. I wish both to show the historical conditions within which Indian tea became possible and also to demonstrate how synchronous events in South and East Asia were directly linked.

\section{I.}

\section{Canton and Free Trade}

When the British were awarded the Bengal diwani, or the right to collect revenue, from the Mughal Empire in 1765, Assam was ruled by the five-hundred-year old Ahom kingdom, which had reconsolidated its position by fighting off Mughal forces only earlier in the century. Thus, "Assam lay outside Mughal and thus early British India." As governor-general Lord Charles Cornwallis wrote in 1792, "we know little more of the interior parts of Nepal and Assam than those of the interior parts of China." 9

The wars of Burmese invasion (1817-24) brought the Company closer. ${ }^{10}$ The British arrived with the stated goal of only securing their own holdings by fending off the Burmese, who conceded defeat in 1826. But during the battles, an officer named Robert Bruce supplied arms and troops to help the Ahom king Chandra Kanta. ${ }^{11}$ Bruce, who decided to permanently reside in Assam, later reported to his younger brother Charles (C.A.) that he had spotted 
an indigenous tea plant growing nearby. ${ }^{12}$ In one account, the older Bruce formed an acquaintance with a local Singpho leader who agreed to furnish him with wild tea plants. Years later, after the British had successfully defeated the Burmese and won the Singphos' favor, C.A. Bruce procured leaves from the same leader. ${ }^{13}$

Historian Amalendu Guha showed that despite the "series of civil wars [that] had ravaged [Assam] since 1769," which had cut the local population by two-thirds, the indigenous peoples continued to maintain their vital commercial activities prior to the Burmese invasion. ${ }^{14}$ The people regularly exported items such as raw cotton, lac dye, silk, and metals to Bengal. Such exchange was conducted through rent in kind and barter, and the British replaced the Assamese khel system of revenue, based upon kinship relations, with a policy of cash payment, extending the system they had established in the Bengal Presidency. Initial attempts at economic reform, however, failed to incorporate Assam into the British capitalist economy. Currency was simply transmitted back to Calcutta, and rent in kind continued, if the peoples did not flee their lands altogether. ${ }^{15}$

Successive governor-generals recommended that the Assamese peoples, unproductive with the land, be displaced from their homes and their lands given to British capitalists willing to invest in and manage export-oriented cash crops. ${ }^{16}$ Early suggestions included sugarcane and indigo, along with tea. By 1834, India governorgeneral William Bentinck issued a parliamentary minute to form a Tea Committee commissioned to investigate prospects for tea production in India. Five years later, a group of London merchants formally created the private Assam Company, two-thirds of the government's garden were given to the company free of rent for ten years, and the employee infrastructure remained continuous from state to private hands.

The tea capitalists benefited from simultaneous developments in the opium and tea trade of Canton, which gave urgency to any project increasing British control over tea production. From the 1784 Commutation Act $^{17}$ to the dissolution of the East India Company in 1833, the tea imports of the Company - which held a monopoly on tea sold to the British and on opium sold to the Ging - doubled from 16 to 33 million pounds. Well over sixty percent of the tea came from the Fujian region of south China, where family farms coordinated a steady supply of tea moving from the Wuyi Mountain area to Canton. ${ }^{18}$

The agreement reached between the Company and the Canton merchants, known as the thirteen cohong (gonghang) merchants, was formed haphazardly. Samuel Ball, the Company's resident tea 
inspector for two decades (1804-1826) who had acquired a decent understanding of the Chinese language, claimed that the cohong system owed its eighteenth-century origins to British "ignorance of the language" and the subsequent inability to prevent "the efforts of the Chinese to establish some form of monopoly."19 In other words, the formal trading rights with the Canton cohong merchants recognized by British private traders were in fact nothing more than the informal domination of a dozen Chinese trading houses. But both the British and Canton sides accrued obscene profits from their respective businesses.

The implications of the tea and opium trade were staggering. By the 1830s tea represented one-tenth of all revenue generated in England and the entirety of the Company's trade profit. ${ }^{20}$ As for opium, historian John Richards showed that opium profits until 1840 represented five to ten percent of the Company's total revenue including land taxes. ${ }^{21}$ Even during the Company's heyday, its Auditor-General T.C. Melville stated bluntly in 1830, "I am prepared to say that India does entirely depend upon the profits of the China trade." ${ }^{22}$ In the 1830 s, however, the British state ended the Company monopoly, and the cohong responded with increased prices and tactics which angered British traders, who clamored for war against the Canton protectionists (as Karl Marx remarked, "in this strange Indian history ... the Indian monopolisers were the first preachers of free trade in England"23).

Sudipta Sen has shown that such free trade rhetoric could be traced to the 1793 Settlement's stated intention to free exchange from the hold of local despots. ${ }^{24}$ For Sen, the British occupation of Bengal operated within the twin logics of free trade and state enforcement. Sure enough, violent measures in Assam and Canton became justifiable in the name of utilitarianism - measures such as the displacement of the Assamese from their land and the opium wars waged against the Ging. In the years preceding the war, Tea Committee officials promoted Assamese tea by bemoaning the inconvenience of buying tea from China in the same idiom brandished by warhawks. In 1834 Bentinck invoked the necessity of "our Empire" to "annihilate the Chinese monopoly" with tea grown in its own colonies. ${ }^{25}$ The rest is a familiar story. The 1842 Treaty of Nanjing solved the cohong monopoly problem by creating five treaty ports and ceding Hong Kong to Britain, a landmark in the history of unequal treaty law. As its flipside, Assamese tea obviated dependence upon the Chinese through the import substitution of tea production. In this specific sense, the cultivation of Assam tea was the continuation of the opium wars by other means. Now let us turn to the actual history of tea production in upper Assam. 


\section{II.}

\section{Assam, 1836-1850}

The Land: Utility and Science

The intellectual legacy of liberal utilitarianism central to both land dispossession in Assam and war in China was also acutely expressed in the thought of British officials responsible for transferring tea production to South Asia. Such men framed the land, the plants and the laborers in a language of science and precision, which derived from the utilitarian idea that abstract principles of efficiency could best guide political and economic affairs. These principles developed as both the outgrowth and repudiation of the physiocratic ideals behind the Settlement. In 1813 James Mill, drawing upon Malthus and Ricardo, attacked the zamindar landlord system for imitating European aristocracy. Instead of leaving rent to the arbitrary discretion of the zamindar, he argued, the state should take a direct approach, assessing land value and administering a precise rent system.

Mill's views were influenced by the complex law of rent, which Malthus had purportedly discovered in 1815 and which had been subsequently revised by Ricardo. ${ }^{26}$ Briefly, the law stated that land value, or rent, could be calculated scientifically. With the assumption that land, with added labor, was the primary source of economic value, Mills argued that soil quality should be fully measured and quantified in order to determine an average, or normal, rate of profit. The "normal rate of profit" would represent the quality of the worst soil and would be subtracted from every farmer's yields to determine how much surplus the state could claim. The surplus represented the land's value, which would be paid as "true rent." In other words, farmers on high quality land would pay high rent, and farmers on poor land would pay nothing.

Given the law's scientific precision, however, Mill feared it would be abused without stringent regulation: "there would be no security that a rapacious middleman [i.e. the zamindar] would not exact more than the true rent and do untold harm to the country." 27 Consequently, Mill recommended an assessment of all lands, the beginnings of the infamous colonial surveys:

To determine the rent of land in India . . could only be done by a minute inquiry into the yield of different soils, the costs of production, and the history of agricultural prices. ... [This meant] an entire reorganization and expansion of the judicial system, a complete overhaul and reshaping of the administrative service, the survey and registration of all landholdings, and a scientific assessment of the land revenue based on detailed statistics of agricultural production. ${ }^{28}$ 
Although utilitarianism's basic principles originated in England, they were first tested in India, where state powers were more extensive. India became a colonial laboratory where "the movements of English life tested their strength and fought their early battles." ${ }^{29}$ In short time, surveys were ordered throughout the empire. ${ }^{30}$

It is within this moment of extensively surveying land and nature where we can best locate the language of scientific improvement permeating the commercial cultivation of tea in Assam. The utilitarian school supported a scientific view of nature insofar as value was framed as an autonomous thing emanating from the soil, demanding objective analysis. The Tea Committee's task was to investigate, uncover and cultivate the inborn qualities of the Assamese soil and harmonize it with Chinese tealeaves. The spirit was best captured by Bentinck, who argued that the task at hand was the "naturalization of . . . foreign plants and vegetables, the natives of climates very different from our own." Although other plants had already failed to grow in India, such failure was attributed to the soil's inadequacy. The key to new ventures was isolating "a peculiar soil, united to a particular climate" and harmonizing it with the plant. Through a scientific understanding of Chinese plants, the British believed they could successfully grow them elsewhere. But officials also wished to perfect the plants. As one famously noted: "[W]hen the skill and science of the Europeans, aided by thermometers, \&c, shall once be applied to the cultivation and preparation of tea in favourable situations, the Chinese tea will soon be excelled in quality and flavor." 31

In January of 1836, a scientific panel composed of three men, described as "two former botanists" and a "geologist,"32 accompanied C.A. Bruce, who was familiar with the terrain, into northeast Assam to examine native plants and assess the prospects for establishing nurseries. They decided that importing Chinese plants would be superior to cultivating the "wild ... jungly stock" of Assam. ${ }^{33}$ Once the Chinese plant was introduced, "it may be expected that the indigenous plant of Assam will lose ... [its] bad qualities." To guarantee this mutation, "the pollen of the Chinese plant must be applied to the stigma of those of Assam" repeatedly. ${ }^{34}$

In May, Bruce was promoted to Superintendent of Tea Forests and given the task of growing the plants on a tight budget. On October third, G.J. Gordon, an opium trader sent to buy tea plants and hire teamakers from Canton, wrote that his "Chinamen" had arrived. He brought three laborers, two of whom could make black tea. ${ }^{35}$ By the end of the year, Bruce and the teamakers had successfully grown and sent a batch of plants to Calcutta. A good practitioner of science, he took detailed notes documenting the experiments. 
The Seeds and Teamakers: A Second History of Circuits of Exchange

As Bruce's concern was long-term profit, he framed his experiments in terms of large-scale and future reproduction. For example, tea plants did not naturally improve with age, so they "would be almost useless for Tea manufacture, as it is the young leaves, from young trees, that produce the best Teas." ${ }^{36}$ Therefore every three years, large tracts of land would be cleared and burnt down. Once burnt, the plants would rebound with "vigor," and the fortunes would multiply, "for, from every old stock or stump cut down, ten to twelve more vigorous shoots spring up." 37 Thus, although the plants owed their genesis to Chinese merchants, Bruce envisioned a plantation in his own image. With each generation, the tea plants would become less Chinese, more Indian, and ultimately optimally conditioned by British botany.

Before he could arrive at that point, however, he needed more seeds and men. The seeds came easily enough. In 1837, Bruce received the first large shipment of 1,609 plants, some "healthy" and some "sickly." ${ }^{8}$ The Chinese plants were an average three feet in height, but the indigenous Assamese plants were "four or five times the size of theirs." ${ }^{39} \mathrm{He}$ waited for the plants to produce seeds, compared the Assamese and Chinese samples, and planted them under various conditions. Over the next year, he received shipments of eight, seventeen and fifty-two thousand plants. It was no surprise that by 1855, records noted that the companies in Assam had "tea seed, mostly China, in excess of what they could use for their own plantings." 40

Bruce isolated three factors for cultivation: rain, soil and shade. For example, he noted that plants transported in the sun and rain would generally survive; from shade to sun in the rain, more would die; and from shade to sun in "uncongenial soil" with much rain, "not one in fifty will be alive the third year." He recommended cutting down the wild plants and harvesting new specimens at low heights, "dwarfish like the Chinese plants." He believed the "Singpho territories are overrun with wood jungle, and if only the under wood was cleared, they would make a noble Tea country." 41 And he respected the delicate economy of each creation, recommending watering the roots but "above inundation" and letting the plants mature in robust soil "provided it were planted in deep shade." 42

Interestingly, Bruce's tract represented probably the earliest British knowledge of Chinese teamaking ever, for, despite a century-long trade with Canton, merchants had no prior knowledge of how or where tea was cultivated. The inspector Ball had con- 
fessed in a footnote, "I have never seen tea made for sale." ${ }^{43}$ The only clue regarding the origins of the seeds and men is a brief line in Bruce's recorded conversations; he noted that the teamakers had come from "Kong-see," on the mountains, about 40 days journey by water to Canton, and two days journey from the great Tea country "Mow-ee-san." ${ }^{44}$ Referencing Fortune's map, one recognizes that "Kong-see" was a reference to Jiangxi and that "Mow-ee-san" was really the Wuyi mountain (Wuyishan) range. Bruce himself had no idea about the histories of the land and peoples of these areas, but, pushing our analysis further, such histories help disclose the deep connections between global trade and patterns of agricultural and commercial development in southern China. That is, they provide an entry point into investigating the origins of the tea seeds and tea makers who traveled in Assam, origins which were rendered opaque by their commoditization in the markets of Canton.

For starters, we can trace the men and plants back to southern China by looking at their teamaking techniques. The two men were black teamakers, but English "black tea" actually refers to Chinese oolong, or semifermented, and red, or fully-fermented, teas (qingcha and hongcha). ${ }^{45}$ Biochemist and historian H.T. Huang concluded that red tea was not widely produced until the 1850s, which means the British had been drinking oolong tea the previous two centuries. ${ }^{46}$ Huang's conclusion is confirmed by Bruce, who detailed that the two men fermented freshly-picked leaves by drying them in the sun but only "permitted [them] to dry about two hours, being occasionally turned." ${ }^{47}$ The time limit means the men made semi-fermented tea, verified by recorded descriptions for the method of making the dark tea of Fujian's Wuyi mountains. An anonymous author in the 1735 compilation Continuing the Classic of Tea wrote that picked Wuyi tea leaves are "placed on bamboo baskets and exposed to the wind and sun." After the "green color is a little faded they are stir-fried and oven dried." ${ }^{48}$ In other words, the semifermented process. ${ }^{49}$

How the Wuyi mountains of Fujian became a region of specialized production is best explained by broad changes from the Ming and Qing dynasties. During the Ming, tax policies were collapsed into silver payments, which drew massive amounts of bullion from Japan and Peru into a burgeoning economy and population, spurring trade in ceramics, silk and tea for silver. ${ }^{50}$ Much like opium during the Qing, this extensive coastal trade had deep implications for inland economic change. For instance, Robert Marks has argued that with population growth, farmers "increasingly turned much of their farmland over to producing commodities that were sold in the market." ${ }^{51}$ Marks' research supports Hill Gates' claim that southern Chinese societies accurately fit the category of petty capitalist 
production, in which a household produces items for home usage but also depends "on engagement with the market, including the buying and selling of labor power" for continued reproduction. ${ }^{52}$ But the family-based arrangements were qualitatively different from London factories or New World plantations insofar as they tempered market demands by withdrawing their labor from the market." ${ }^{53}$ Another example of mixed economies at local levels was the persistence of rent in kind. While state taxes were uniformly paid in silver, many landlords asked for crops instead. In Fujian, "where small-scale cultivation of tea was common, tenants had to sell their tea to landlords." 54

By 1840 , of the thirty million pounds of export tea purchased by British ships, ninety percent came from the Wuyi tea country. ${ }^{55}$ Its growth followed the pattern of long distance trade and global markets spurring greater production from decentralized household economies. It was a "golden era of tea production." Expansion encouraged migration to peripheral areas, and hills unsuitable for grains were converted into tea farms. ${ }^{56}$ During the 1820 s, a commentator noted, "[t]he mountains are wasteland without grain crops. . . . [T]he mountain land is rented out to Jiangxi people who open up cultivation to plant tea." 57

Further evidence of commercialization can be found in local sources. Gazetteers catalogued stories about tea as early as the sixteenth century. In a 1737 story entitled "Record of a travel through the Wuyi Mountains," the author travels through the Wuyi passes during a storm, finding refuge in a cave where he meets indigenous peoples who offer him tea leaves. ${ }^{58}$ Later, the romantic travel journal entries were accompanied by the framing of tea as a commercial crop. In the 1769 gazetteer, one entry noted:

At the start of the Ging, Wuyi was considered a place of refuge and escape. . . . [Its] wastelands have recently been reclaimed and used to grow tea. . . . For a temporary period of time, it becomes crowded with tea pickers, numbering over ten thousand. ${ }^{59}$

Records from the neighboring Jiangxi also corroborate the narrative: during "the spring there is a sudden influx of hundreds of thousands of migrants from Jiangxi." People moved because Jiangxi "land is poor, and those who till have to eke out a living by picking tea in Fujian." 60 The oolong teamakers who somehow found their way to Assam were likely one of these men. That they were willing to migrate across the world for decent wages is partially explained by their transient status as temporary laborers back home.

Following the tales of local records, we wind up with a fairly complex relationship: Bruce had brought the men to Assam to 
teach him the Chinese way of making tea, but in the larger scheme, the production of darker teas had already been influenced by British taste. ${ }^{61}$ It was British preference that caused so many laborers to learn the methods for semifermented tea; it was in order to meet British demand that so many Jiangxi men and women turned to picking tea; and it was the British trade at Canton that brought them into a fateful encounter with Gordon which ended with them on a ship to Assam (six months after which, two would be dead). ${ }^{62}$ Thus, just as the British tea plantations in Assam would not have been possible without the work of the Chinese, we can also qualify our history by arguing that Chinese manufacture of semifermented and red tea would not have been possible without the British.

\section{The Labor: Batches of Chinamen and Aborigines}

Bruce and the Company took a similar approach to laborers as they did with seeds: they emphasized utility, so they imported as many men as possible, but they also emphasized efficiency, so they prioritized effective but cheap workers, which eventually led them to the neighboring regions of Assam. Just as tea seeds were trafficked wholesale, so too were local populations.

The Company's labor policy initially stated that "Chinamen may be procured in any number if proper means are used to obtain them." ${ }^{63}$ The Company wrote to merchant houses in Singapore, Batavia and Penang "to secure as many capable hands as can be picked up from the Chinese Junks." 64 In the hunt for teamakers, the Company would exhaust all resources available to members of the British colonial world. First, the Company looked for Chinese intermediaries in Calcutta. Three years earlier, the Tea Committee had sought to hire a Chinese migrant doctor named Lumqua to help translate, but the government refused to pay for his services. In 1840, the private Assam Company hired him. Lumqua then introduced the company to another Calcutta Chinese man named Ekan, and together they recruited potential Chinese apprentices from domestic and overseas markets. In 1837, a reported 362 Chinese lived in Calcutta. ${ }^{65} \mathrm{~A}$ famous legend among the contemporary Chinese community in Calcutta recalls that the first Chinese person in colonial India was a man named Acchi ${ }^{66}$ who arrived in the 1770s on a British ship. Acchi sought permission from the governor-general to employ "Chinese who have deserted from Macao ships and remain in Calcutta without any apparent means of subsistence." 67 But Acchi was dead by 1783; nevertheless, a steady influx of Chinese migrants, both owners and laborers, 
continued arriving, working as cabinet builders, water tank cleaners and sugar farmers. ${ }^{68}$

Acchi, Lumqua and Ekan shared a formal similarity as Englishspeaking Chinese who acted as middlemen for the waves of Chinese labor passing through India. We can try to understand their role by examining the interchange between South, Southeast and East Asia. Among the Chinese in Southeast Asia, a representative acted as "an intermediary from the Chinese community." He would handle communications and take responsibility for things like registration, marriage, birth, and death paperwork. ${ }^{69}$ The similarities between Southeast Asia and Calcutta here provide rudimentary grounds for suspecting their integration within a larger colonial trading universe. For over a century prior to the Assam Company, traders, miners, and shipbuilders left Qing China in vast numbers to places like Vietnam, Cambodia and Siam. ${ }^{70}$ These men relied upon networks established in Qing China, but of course they overlapped with the movement of Dutch, Portuguese and English ships. Until the late 1700s, Calcutta, and hence the English, remained peripheral to the Southeast Asia trade, and the British firms which served as entrepôts for the Assam Company's Chinese labor in 1840 had only recently begun working with the established Chinese networks. The cornerstone would have to be Singapore, where Ekan traveled to recruit apprentices. Established in 1819, Singapore quickly became a trading hub for movements spanning from Dutch Batavia to Bangkok. According to Trocki, Chinese traders landed in Singapore to buy more supplies and various crops to grow in the surrounding areas. Crops demanded workers, and hence Singapore "became the headquarters of Southeast Asia's Chinese labor exchange." Migrants would secure jobs in the city first and then were shipped to surrounding plantations. ${ }^{71}$

The most common organizational form was the lineage and locality-based kongsi (gongsi). The kongsis were independent of and sometimes more influential than the local governments. Atop the hierarchy, the taukeh ${ }^{72}$ often manipulated workers by setting low wages and high prices and keeping them in debt. With the introduction of opium and its addictive drain on wages, savings never quite materialized as the workers hoped.$^{73}$ The established hierarchy helps explain how Ekan could quickly secure so many apprentices for the Assam Company.

Prior to Ekan's trip, workers had been arriving at Assam in waves. In November 1839, a "batch" (Bruce's term) of fifty came from Penang; in January 1840, 64 followed. Finally, in February, Ekan's batch of 247 Chinese from Singapore arrived in Calcutta. ${ }^{74}$ Most of Ekan's men were laborers simply looking for jobs, not from the Fujian tea countries (in the words of one observer, "every man 
with a tail was supposed to be qualified to cultivate, manipulate and prepare tea"75). Troubles accompanied them. Upon landing, five were wounded in a disagreement stemming from Ekan extorting three dollars from each man's advances. In March, they fought with the townspeople of Pabna, killing four locals. The men refused to leave until their friends were released from prison, and after three months, the Company dissolved their contracts and abandoned them. The disaster of wholesale importing Chinese labor left a bad taste with the Company, and subsequent missions focused solely on finding select Chinese teamakers to team with apprentices from domestic areas. ${ }^{76}$

With the refinement of the Company's recruitment strategies, we begin to discern a homology between its attitudes towards seeds and towards the laborers. With seeds, the first step was to exhaust resources available to British merchants, collecting as many seeds as possible via men like Gordon and Fortune. Inevitably, some seeds would be dried or ruined in transport, but the rest were useful for experimentation. A lack of immediate communication along with impromptu planning resulted in a seed surplus, and many were not used. With labor, as many batches as possible were secured from overseas, but many men turned out to be bad seeds, useless to Bruce. He complained that too many were arriving without being filtered for quality. Hence a good portion of the labor was dismissed, and the Assam Company resolved to only hire cheap, available workers.

And just as the officials debated the relative values of Assamese and Chinese tea plants, they also debated the relative qualities of Indian and Chinese labor. Unlike with plants, however, the downtrodden status of the Indian became a virtue. For example, Ball wrote that where the Chinese worker "has a good substantial mud or brick house, generally thatched," the Hindoo is "satisfied with a small mud hut or shed, which he hardly inhabits by day." 77 He concluded the Hindoo was a subject "of privation" without the comforts of the Chinese laborer. "So far as the wants of the two people, and wages of labour are concerned," he wrote, "India possesses no small advantage over China for the successful cultivation of tea."78 In other words, native labor was better acclimated to native soil.

But just like the indigenous Assamese plant, the indigenous worker needed improvement. It needed to learn Chinese qualities, such as tea-drying skills, but it also needed to be cleansed of defects. Specifically, Bruce complained chiefly about laziness and the Assamese addiction to opium. Unless the British government could ban opium in Assam, then "the thousands that are about to emigrate from the plains into Assam, will soon be infected with the Opium mania." 79 
The hypocrisy should be obvious: the lucrative tea business Bruce was trying to steal from Canton was largely fueled by the Company's ability to popularize opium harvested in Bengal, Benares and Patna. Assamese addiction was directly related to British encouragement of opium farms. Further, the impasse of Assamese addiction highlighted the tension of trying to produce consumers of British goods while also exploiting them for their work. John Richards wrote that although "preconditions for widespread addiction already existed" in the "substantial use of opium" in Indian society, "[ $p$ ]aradoxically . . . the Indian subcontinent did not suffer the ravages . . . that so devastated China and the Southeast Asian countries." ${ }^{80}$ Perhaps Richards' paradox becomes more transparent if we consider that India and China represented different things to the British Empire. In order to turn a profit on occupation, the British needed Indians to be good producers. But in order to profit from trade, the traders needed the Chinese to be good consumers. For example, we have the emblematic figure G.J. Gordon, who was responsible for bringing the first group of Chinese teamakers to Assam in 1836 and who also made a living dealing opium to Canton through a private firm. His combined success depended upon both Chinese addiction and Indian sobriety.

But because Bruce saw few alternatives in Assam, the opium problem "point[ed] out the utility of introducing a superior race of labourers, who would not only work themselves, but encourage their women and children to do the same." ${ }^{81}$ According to Bruce, the Assamese refused to allow their women to work on the tea plantations, but costs could be minimized if whole families of workers could be transplanted. By the 1860s, Company documents recorded that families, not just individual males, had begun to migrate and live on the plantations. The integration of women into the workforce was gradual; in 1861, only ten percent of plantation workers were women. But numbers continued to climb since plantation managers understood that the settlement of whole families guaranteed a much more stable workforce. ${ }^{82}$ Today, nearly half overall and over eighty percent of tea pluckers on Indian plantations are women. ${ }^{83}$

The creation of a self-reproducing Indian workforce emerged as a recurring Company theme. Like the Chinese tea plant endowing its best traits onto the Assamese variety, Bruce envisioned replacing the original Chinese teamakers with natives. He optimistically speculated that if his original twelve teamakers could teach their art to twelve "native assistants," then the latter "may be available next year to manufacture Tea independently." ${ }^{84}$ Looking for South Asian workers, the Company again relied upon recruitment drives. Eight agents were sent out at the end of 1839, resulting in batches 
of 400,156 , and 500 coolies over the following year. ${ }^{85}$ Bruce remained confident that he could find enough work for the men as part of his visionary tea plantation of the future. ${ }^{86}$

Bruce was also aware of the dangers of exhausting the workers' productivity. He often spoke of improving their quality of life through employment, echoing the tropes of liberal utilitarianism. The prohibition of opium, for example, would "benefit [the] people, and save those who are coming here." 87 Unsurprisingly, however, the treatment of plantation workers became notoriously cruel over time. Kaushik Ghosh has documented how plantation officials deemed the Assamese groups as opium junkies, forcibly importing workers from the Chotanagpur region of Orissa instead. Known as Dhangars, they had been targeted for export abroad to replace New World slavery, carrying the reputation of a wild, aboriginal nature that could be channeled into productive work. In the late 1850s, Chotanagpuris were recruited for work in Assam, tied to plantations through indenture contracts "of three to five years... enforced with the threat of imprisonment and heavy fining of any deserter," administered by agency houses whose sole purpose was recruiting bound labor. ${ }^{88}$ The poor treatment of workers was documented extensively in government records of the late nineteenth century, in which British officials were sent to investigate the gardens' conditions. Such activities also confirm the larger pattern of British officials, reliant upon local intermediaries, trafficking things and people for the sake of establishing a profitable model for the Indian tea enterprise.

\section{III.}

\section{The Real Value of Tea}

From the beginning, the plantations of Assam relied upon a transregional flow of capital, raw materials and labor. An enterprise with little connection to the local people, the Assam Company's mission was to import a hitherto luxury commodity from abroad and reproduce it on a mass scale using land hitherto perceived as a wasted resource (best captured in the series of policies sharing the title "The Wastelands Act"). In the end, Bruce and his men decided that a combination of Assamese soil, Chinese plants and imported labor from Orissa and Bihar was the optimal mix for the enterprise. Each of these items was treated ahistorically, objectified, analyzed and compared in their immediate properties.

To end this essay, I will briefly argue that the classical debates from political economy over the relationship between land and value are instructive for thinking more rigorously about the historical processes through which these various things were ripped 
out of their prior contexts, transported long distances and ultimately found their way onto a British garden in northeast India. The dynamic circuitry which made Assamese tea production possible also reveals the limits of the timeless, scientific approach to political economy permeating the rhetoric of Bruce and of his contemporaries.

Most famously, Karl Marx criticized the Ricardian idea that value, qua rent, was something isolatable in the soil and which could be treated as a thing. ${ }^{89}$ For Marx, Ricardo's theory was not complex enough to understand that the value of land was a socially contingent formation. Where Ricardo believed rent resulted from differences in land quality, given constant and equal amounts of capital and labor, Marx argued that constant amounts of capital, labor and land were a fiction. Due to the historical complexity of differential capital investment and alterations to the land, it would be impossible to say whether value was a result of the labor, the capital or the soil. ${ }^{90}$ Rather than a thing, value belonged "to a definite historical formation of society, which is manifested in a thing and lends this thing a specific social character." ${ }^{91}$ Land was a precondition for creating commodities of value, but the true source was labor. He wrote:

Value is labour. Therefore surplus-value cannot be earth. Absolute fertility of the soil effects nothing more than the following: a certain quantity of labour produces a certain product - in accordance with the natural fertility of the soil. The difference in soil fertility causes the same quantities of labour and capital, hence the same value, to be manifested in different quantities of agricultural products; that is, causes these products to have different individual values. ${ }^{92}$

Marx's critique relocated the focus of political economy from objectified things onto the process of production. By emphasizing the conditions in which labor and its representation as labor-power became the measure of value, Marx highlighted the importance of paying attention to the geographically broad and dynamic socioeconomic conditions that made industrial commodity production such a profitable and dominant form in the nineteenth century. Thus, while Bruce fixated on leaves, soil and labor as static things, their profitability was in actuality made possible by the violent imposition of the Company over the land, overseas migration and business networks, and the laborers' disciplined hours of working the plantations. In a circular fashion, the utilitarian belief in soil as the source of value spurred a mass of activity by Bruce and his botanist-capitalist partners which itself endowed tea with value. The powers of soil, in other words, were "as much the product of history as they [were] of nature." ${ }^{93}$ Further, as the history of the tea industry's creation became forgotten and overshadowed by Bruce's 
fixation on the land and its plants, so too did the spatial logic of capital. Without that spatial reach into southern China and other areas, however, tea could never have become the object of so much British investment in the jungly wastelands of northeast India.

Correlatively, the proponents of land rent were also open to criticism for treating agriculture as somehow different from capitalist industrial production. Marx dismissed the idea that farming was more natural than the factories he saw in London since ultimately both followed the principle of capital begetting capital, with labor at the system's heart. The farmer, he wrote, "produces wheat ... in much the same way as the manufacturer produces yarn or machines." 94 The industrial dimension of the plantation explains one of the most striking features of the Assam experiments: their scale. Although not totally unlike the specialized crop rotations in late imperial China, Assam's tea industry was marked by historically rapid speed and breathtaking size. The landscape was transformed in less than a decade, as employees were ordered to bring in as many plants and workers as possible. They had the private capital to subsidize expenses and did not turn a profit for years. In fact, they did not break even until $1849 .{ }^{95}$ But once they had, the investments in dead plants, failed seeds and useless workers - all the initial expenditures paid off.

The connections to the factories of England not only help explain the scale and reach of the tea industry, they also demonstrate a central argument of this essay: that the tea plantation was made possible by, and made further possible, the vast and uneven spatial integration of different regions into overlapping economic circuits. While Bruce focused solely upon harmonizing the land and the seed as the secret to his business venture, the tea plantation really emerged from the mutual relationship between highly active trade circuits encompassing northeastern India, China and Southeast Asia and the plantation space itself.

It would thus be salutary for scholars of plantations to continually reflect upon the way plantations were, and continue to be, made possible by movements far more dynamic than a static, designated locale such as Assam or Canton. Plantations, although labeled rural, borrowed much from the factories and workshops of urban production, and while they were animated by the specificity of local populations, climates and land, they also constantly, and mutually, borrowed techniques of management, recruitment and organization from their siblings around the globe. In the case of Indian tea, the relationship between value and history is best illuminated when we consider the plantation as one effect of a broader trajectory, irreducible to single actors or populations but rather concurrent with violent social processes. The Assam plan- 
tations resulted from expansive land appropriation in India, the discipline and recruitment of peasants from Orissa and Bihar, battles over the right to monopoly in Canton, specialized tea harvesting in the tea countries of Fujian, the establishment of Singapore as the labor hub of Southeast Asia, and the extension and application of a British political economy tradition emphasizing utility, improvement and science.

Ultimately, the Assam tea plantations became a deeply ingrained institution in its immediate vicinity, as Assam and tea are virtually synonymous today. But the Assamese tea plantation's origins and its relationship with the global export crop economy would become impossible to explain the moment one fails to consider the spatiotemporal dynamics of colonialism and commodity capital in nineteenth-century Asia.

\section{Acknowledgments}

I would like to thank Ralph Austen, Mark Elliott, Carol Gluck, Dorothy Ko, Eugenia Lean, Mark Mazower, Adam McKeown and the JHS reviewers for their comments. Anupama Rao was especially responsible for major improvements to this piece. I benefited from a spirited discussion with the Columbia/NYU graduate student collective of Spring 2008. Thank you to the editors of this issue, particularly Piya Chatterjee, for offering this opportunity and their assistance. And I am grateful to Reiko Rogozen for her patience and support.

\section{Notes}

${ }^{1}$ Karl Marx, Capital, trans. Samuel Moore and Edward Aveling, ed. Frederick Engels. (Moscow: Progress Publishers, 1887), Marxists Internet Archive. http://www.marxists.org/archive/marx/works/1867-c1/ch01. htm.

${ }^{2}$ Rebecca Karl, "The Burdens of History: Lin Zexu (1959) and The Opium War (1997)," in Zhang Xudong, ed., Whither China? Intellectual Politics in Contemporary China (Durham: Duke University Press, 2001), 237.

${ }^{3}$ Exhaustive detail about the opium trade will not be included here, but will be referenced periodically. An understanding of the well-known story of the opium wars is assumed for this paper, but further details can be found in the endnotes, especially Carl Trocki, Opium, empire and the global political economy: a study of the Asian opium trade, 1750-1950 (New York: Routledge, 1999), Hoh-cheung Mui and Lorna Mui, The management of monopoly: a study of the English East India Company's conduct of its tea trade, 1784-1833 (Vancouver: University of British Columbia Press, 1984), and John Richards, "The Opium Industry in British India," Indian Economic \& Social History Review 39 (2/3), 2002. 
4 The precise similarities and differences between British India and China have been a continually debated theme for much of the last century. A brief survey of recent scholarship stresses that although the British tried to manage their imperial positions as part of the same empire, they employed different strategies for different regions. Fa-ti Fan (2004) has argued that the clearest difference was that the British saw Canton and later Hong Kong as places of trade and refused attempts to invest in and control overseas businesses there. Elsewhere, James Hevia has offered a longer meditation on the question of why the British never attempted to fully occupy China as it had India. First, the occupation of Bengal and northern India had cost the empire too many resources in the administration of law and commerce for the government to seriously consider even more territorial expansion. Further, due to the size of the Qing, its large population and "a lingering sense that China was slumbering and would someday awaken to reclaim greatness - European powers chose to manipulate, modify and work through existing political authorities in China." Finally, England's policies as a whole were overshadowed by anxiety over its battle with imperial Russia in the hyped Great Game between the two powers. Hevia's descriptions may register with the late nineteenth century, when administrative bureaucracies cost the British dearly, but their applicability becomes questionable for earlier in the century, when the British were more ambivalent about fully investing in overseas colonies. Nonetheless, Hevia provides a useful starting point for inquiry, and the rest of this paper will be similarly guided by the question of difference between Anglo-Indian and Anglo-Chinese colonialism. James Hevia, English Lessons: The pedagogy of imperialism in nineteenth-century China (Durham: Duke University Press, 2003), 13, 24-25.

${ }^{5}$ David Harvey, Limits to Capital (Verso: New York, 1982; reprinted 2006), 373.

${ }^{6}$ Harvey is especially useful as a supplement Hevia's reading of the British-India-Qing triangle at this moment. Hevia described the dynamic as a productive process and relied upon Deleuze and Guattari's twin notions of reterritorialization and deterritorialization, arguing that the more the capitalist machine, here expressed in the British empire, deterritorializes "in order to extract surplus value from [material flows], the more its ancillary apparatuses, such as government bureaucracies and the forces of law and order, do their utmost to" repdeploy "European cultural, social and poliitcal forms" to provide a "life-support system for further acts of imperialist deterritorialization." Harvey agrees, stating that such a process epitomizes the contradictory tendencies of capitalist development: "On the one hand spatial barriers and regional distinctions must be broken down. Yet the means to achieve that end entail the production of new geographical differentiations which form new spatial barriers to be overcome." These differentiations "must be understood as something actively produced and sustained by processes of capital accumulation." Harvey, unlike Hevia, emphasizes not only the productive but also the spatial dimensions to colonialism; that is, how capital transforms not only a place in isolation but also its location relative to others. For example, Assam's location was transformed by the British connections to north India and to Canton, and as a result its land and people were profoundly affected. Hevia, 22; Harvey, 417; Harvey, Spaces of Global Capitalism: towards a theory of uneven geographical development (New York: Verso Books, 2006), 65. 
7 Robert Fortune, Two visits to the tea countries of China and the British tea plantations in the Himalaya; with a narrative of adventures, and a full description of the culture of the tea plant, the agriculture, horticulture, and botany of China (London: J. Murray, 1853), back page.

8 David Ludden, Where is Assam? Using geographical history to locate current social realities (Guwahati, Assam: Centre for Northeast India, South and Southeast Asia Studies, 2003), 12-13.

${ }^{9}$ Cornwallis, quoted in A.C. Banerjee in H.K. Barpujari, ed., The Comprehensive history of Assam: from the pre-historic times to the twelfth century A.D. (Guwahati : Publication Board, Assam, 1992), 301.

10 Amalendu Guha, Planter-raj to Swaraj (New Delhi: Indian Council of Historical Research, 1977), 1.

${ }^{11}$ Banerjee, 349.

${ }^{12}$ H.A. Antrobus, A History of the Assam Company (Edinburgh: T. and A. Constable, 1957), 17.

13 Jayeeta Sharma, "British science, Chinese skill and Assam tea: Making empire's garden," Indian Economic \& Social History Review 43 (4), 2006, 437.

${ }^{14}$ Amalendu Guha, "Colonisation of Assam: Years of Transitional Crisis," Indian Economic \& Social History Review 5, no. 2 (1968): 125, 129.

15 Guha, "Transitional," 130.

16 Of course, this representation was false. The Assamese regularly exported to Bengal items such as raw cotton, lac dye, silk, and metals. Items that were cultivated for home consumption alone included betelnuts, rice, peppers, sugarcane and tobacco. The qualities of materials for fiber and sericulture apparently were superior and in great demand elsewhere. But exchange and land policy at this time were conducted through rent in kind and barter, and the British quickly replaced the Ahomese khel system of revenue, which was based upon kinship relations, with cash payments. Guha, "Transitional," 130.

17 There is an exhaustive literature on the Commutation Act. Specifically, see Mui and Mui. On the effect of the tea trade on domestic British life and in British colonies, see Eric Hobsbawm, Industry and Empire: From 1750 to the Present Day (New York: Penguin Books, 1990), 28; and Sidney Mintz, Sweetness and Power: The Place of Sugar in Modern History (New York: Penguin Books, 1985), 141.

${ }_{18}$ Mui and Mui, 146-7. Calculations by Robert Gardella, Harvesting Mountains: Fujian and the China Tea Trade, 1757-1917 (Berkeley: University of California Press, 1994), 37.

19 Samuel Ball, An account of the cultivation and manufacture of tea in China (New York: Garland Publishers, 1980), 342, 345.

${ }^{20}$ Michael Greenberg, British trade and the opening of China, 1800-42 (Cambridge University Press, 1951), 3.

${ }^{21}$ Richards, 159-161.

22 Melville in Greenberg, 14-15.

${ }^{23}$ Karl Marx, "The East India Company - Its history and its results," New-York Herald Tribune, June 24, 1853. http://www.marxists.org/ archive/marx/works/1853/07/11.htm

${ }^{24}$ Sudipta Sen, Empire of Free Trade: The East India Company and the Making of the Colonial Marketplace (Philadelphia: University of Pennsylvania Press, 1998), 121.

${ }^{25}$ Antrobus, 12. 
26 The following explanation is based heavily upon Eric Stokes, The English Utilitarians and India, (London: Oxford University Press, 1959), 87-93.

27 Stokes, 91.

28 Stokes, 77-78.

29 Stokes, xii.

${ }^{30}$ In the case of R.K. Pringle in the Bombay Deccan, see Kumar, Ravinder, Western India in the Nineteenth Century (Toronto: University of Toronto Press, 1968), Chapter 3. The other case concerns Holt Mackenzie in Northern India, in Stokes, 109-116.

31 John Walker in "Papers relating to Measures for introducing Cultivation of Tea Plant in British Possessions in India," 11. Background information on Walker can be found in Antrobus, 258.

32 Charles A. Bruce, An Account of the Manufacture of Black Tea, as now practised at Suddeya in Upper Assam, by the Chinamen sent thither for that purpose: with some observations on the culture of the plant in China, and its growth in Assam (Calcutta: G.H. Huttmann, 1838), 12.

${ }^{33}$ Griffith in Percival Griffiths, The History of the Indian Tea Industry (Weidenfeld and Nicolson, 1967), 47. As Sharma has argued, implicit in such statements was not simply a stated preference for the Chinese beverage already familiar to British tastes but also a remark about the civilizational inferiority of the Assamese groups compared to the Chinese. Sharma, 440-441.

${ }^{34}$ Quoted in Griffiths, 47-48.

35 Gordon in Papers, 87.

36 Bruce in Antrobus, 468.

37 Ibid, 469.

38 Bruce in Antrobus, 467.

39 Ibid, 469.

40 Antrobus, 34.

${ }^{41}$ Bruce, 16.

42 Ibid, 468.

43 Ball, 105.

44 Bruce, 9.

45 The term "fermented" is not entirely accurate. Rather than fermentation, tealeaves actually undergo an oxidization process, but fermentation is the term used most in existing literature.

46 According to H.T. Huang, Ball had recorded a mention of red tea in the 1820s long before it was ever mentioned in a Chinese source. See Ball, 146.

47 Bruce, 1-2.

48 Wang in H.T. Huang, Science and Civilisation in China. Volume 6: Biology and Biological Technology. Part V: Fermentations and Food Science. Joseph Needham: Science and Civilisation in China (Cambridge: Cambridge University Press, 2000), 539.

49 Huang cites two other sources to back up his claim that Wuyi tea is oolong tea. First, the Supplement to the Compendium of Materia Medica [Bencao gangmu shi] said that Wuyi tea is "black and its taste sour." Further, it is a good substitute for those who cannot drink "regular tea," which must refer to green tea. Second, the 1792 Recipes from the Sui Garden [Suiyuan Shidan] noted that the Wuyi drink is "heavy and bitter. ... The tea leaves may be infused up to three times, yet their flavor is not depleted.” See In Huang, 540. 
The description in Recipes matches that of modern day concentrated gongfucha, which is an oolong tea served like thick liquor in contemporary Fujian, Taiwan, Guangdong and Southeast Asia, the areas most tightly connected to the overseas tea trade of the eighteenth and nineteenth centuries. Foreign merchants transliterated gongfucha as Congou tea, and it became the British beverage of choice starting in the late eighteenth century. Thus we can say nearly for certain that the origins of the tea exported from Canton - and hence the tea regions which Gordon was most likely to reach - were mostly from the Wuyi Mountain area. Of the thirty million-plus pounds of tea purchased annually by the mid 1830s, about five million was green tea - either Singlo [Songluo] or Twankay [Tunxi] from Songluo tea country in Anhui. The other 25 million-plus pounds were either Bohea style, which is a transliteration of Wuyi, and Congou style, which was a concentrated version of Wuyi tea. See Mui and Mui, 100 and 105.

One possible counter-interpretation to the above reconstruction is the wide-circulating point that gongfu could be translated as "extra care," "hard work" or "extra time." Some contemporary writers believe that the extra care refers to hongcha procedures, which require the most preparation time. However, while Congou was certainly used to describe hongcha in the late nineteenth century, no texts I could find were willing to associate the eighteenth-century Congou tea purchased by the British with the latter hongcha incarnation. One good explanation is that gongfucha was originally used to describe the best type of tea grown in Fujian. An entry on geography in Continuing the Classic of Tea recorded that "[i]n the Wuyi Mountains of Fujian, the tea on top of the summits are called cliff tea [yancha]. . . The very best quality of this tea is called gongfucha." This passage also allows us to imagine how gongfucha, originally just a description of tea among many others, became a demanded, codified brand name once the British acquired a taste for it and established a quota guaranteeing its regular supply. See Yancan, Xu Chajing (Taibei, Taiwan: shangwu yinshuguan, 1974), juan 4, 26.

50 Sucheta Mazumdar, Sugar and society in China: peasants, technology, and the world market (Cambridge, MA: Harvard University Asia Center, 1998), 211. Dennis Flynn and Arturo Giráldez, "Cycles of Silver: Global Economic Unity through the Mid-Eighteenth Century," Journal of World History 13 (2), 2002, 398. Fan Jinmin, Jiangnan sichou shi yanjiu [Historical Research on the silk of Jiangnan] (Beijing : Nongye chuban she : Xinhua shudian Beijing faxing suo faxing, 1993), 269. South Asia was also affected by such circuits. See Frank Perlin, "Proto-Industrialization and Pre-Colonial South Asia," Past and Present 98, 1983. Flynn and Giráldez also cite K.N. Chaudhuri's Asia Before Europe on this phenomenon.

${ }^{51}$ Robert Marks, Tigers, rice, silk, and silt: environment and economy in late imperial south China (New York: Cambridge University Press, 1998), 335.

52 Hill Gates, China's motor: a thousand years of petty capitalism (Ithaca, NY: Cornell University Press, 1996), 29.

53 Mazumdar, 389.

54 Ibid, 289.

55 Fang, et al. in Xu Dixin and Wu Chengming, ed., Chinese capitalism, 1522-1840 (New York: St. Martin's Press, 2000), 184-5. Mui and Mui, 100. These figures are substantiated by Gardella, 6 citing Wu. Trade from Fujian to Canton was coordinated by middlemen tea brokers. According to 
a witness account, "as soon as [the tea merchants] arrive, [they] place money and a list of what they want in the hands of the brokers, and ask no questions."

${ }^{56}$ Lu Weijing, "Beyond the Paradigm: Tea-picking Women in Imperial China," Journal of Women's History 15 (4), 2004, 22.

57 Gardella, 42.

58 From Wu Juenong, ed., Zhongguo difangzhi chaye lishi ziliao xuanji [Selection of Historical Materials on Tea from Chinese Local Gazetteers], (Beijing: Nongye chubanshe: Xinhua shudian Beijing faxingsuo faxing, 1990), 298.

59 From Wu, 301.

${ }^{60} \mathrm{Lu}$ in Fang et al., 186.

61 One hypothesis is that the British drank fermented teas because only fermented teas could survive the overseas trips from Canton to London.

62 After the initial three men, the second group from Canton arrived in February 1838, five men in total: two green teamakers, two box makers and one canister maker. They had insisted the Committee pay their entire trip from China, including food and board, and as a result they left their advances with families back home and packed "barely sufficient clothing for the voyage," fully assuming they would return. Upon arrival, they "were virtually destitute" and did not have all of their tea-processing equipment. Perhaps even worse, they learned upon arrival that two of the three original men from the first group had already perished. They too probably died soonafter. See Antrobus, 375.

63 Statement quoted in Antrobus, 36.

${ }^{64}$ Quoted in Antrobus, 376. Emphasis mine.

65 Ellen Oxfeld, Blood, sweat, and mahjong: family and enterprise in an overseas Chinese community (Ithaca, NY: Cornell University Press, 1993), 74.

66 Yang Dazhao was his recorded name in standard modern Chinese. According to Oxfeld, Calcutta Chinese today recognize Acchi's name and can relate anecdotes about him and his relationship with Warren Hastings, the former governor-general of British India.

67 Ibid, 72.

68 Ibid, 73. Chinese in Calcutta today are very familiar with different versions of this story, and the legend is also well known to most long-term residents of Calcutta and others in the northeast tea industries.

69 Summarized in Oxfeld, 74.

70 Anthony Reid, "Chinese Trade and Southeast Asian Economic Expansion in the Later Eighteenth and Early Nineteenth Centuries: An Overview," Water Frontier: Commerce and the Chinese in the Lower Mekong Region, 1750-1880, ed. Nola Cooke and Li Tana (Lanham, MD: Rowman \& Littlefield, 2004), 23.

${ }^{71}$ Carl Trocki, "Chinese Capitalism and the British Empire," A paper presented to the International Association of Historians of Asia, Conference, Taipei, December 2004. http://eprints.qut.edu.au/archive/ 00000679/01/trocki_chinese.PDF, 8.

72 This figurehead is commonly referred to in various incarnations of taukeh, tiko, teko and taiko. Trocki's guess is that it is a distinct pronunciation for the term older brother, or dage in modern standard Chinese. Dage often serves as a term for senior members of a business.

73 Trocki 2004, 6.

74 Ibid. 
75 Quoted in Griffiths, 64.

76 Ibid, 379-380.

77 Ball, 338-340.

78 Ibid, 342.

79 Bruce in Antrobus, 474. Emphasis mine.

80 Richards, 154. Emphases added.

81 Bruce in Antrobus, 466.

82 Navinder K. Singh, Role of women workers in the tea industry of North East India (New Delhi: Classical Publishing Company, 2001), 63.

83 Singh, 1, 77. In the context of late-twentieth century Bengal plantations, Piya Chatterjee has recorded how femininity and images of nativeness have become commoditized images in the advertisements of Indian teas produced for overseas consumers. They feature primitive native (Indian) women with an intimate knowledge of the exotic tea plant in the service of civilized European consumers seemingly worlds away. Chatterjee, Piya, A time for tea: women, labor, and post/colonial politics on an Indian plantation (Durham: Duke University Press, 2001), 2-3, 8. For a comparative study in China, see Lu Weijing, op. cit.

${ }^{84}$ Bruce in Antrobus, 465.

85 Antrobus, 384-386. One of the agents, W.S. Stewart, said he collected 637 coolies, all of whom he claimed had died in the night from cholera on the way to Assam. Upon seeing the massive bill for travel, the Board of Directors sent Stewart to Pabna to deal with the unruly Chinese workers "[a]s if in punishment."

86 Ibid, 387.

87 Bruce in Antrobus, 474.

${ }^{88}$ Kaushik Ghosh, "A Market for Aboriginality: Primitivism and Race Classification in the Indentured Labour Market of Colonial India," Subaltern Studies 10, 1999, 8-48.

89 The broad and complex discussions of rent are included in chapters 38-48. I borrow from Chapter 11 of Harvey, who cites the work of M. Ball and B. Fine as important commentators on Marx's incomplete writings.

90 Harvey, 356-357.

91 Marx, Chapter 48. Italics added.

${ }^{92}$ Karl Marx, Capital: Volume III. Chapter 48. http://marxists.org/ archive/marx/works/1894-c3/ch48.htm

${ }^{93}$ Harvey, 337.

94 Marx, Chapter 37, http://marxists.org/archive/marx/works/1894c3/ch37.htm.

95 From Griffiths, 125.

\section{Works Cited and Referenced}

\section{British Parliamentary Papers}

Papers connected with Coolie Trade in Assam, and elsewhere; 1867 (124) L.357.

Papers relating to Measures for introducing Cultivation of Tea Plant in British Possessions in India; 1839 (63) XXXIX.223. 


\section{Chinese Language Sources}

Fan Jinmin. Jiangnan sichou shi yanjiu [Research on the history of Jiangnan silk]. Beijing: Nongye chuban she : Xinhua shudian Beijing faxing suo faxing, 1993.

Lu Tingcan. $\mathrm{Xu}$ Chajing [Continuing the Classic of Tea]. Taibei, Taiwan: shangwu yinshu guan, 1974.

Wu Juenong, ed. Zhongguo difangzhi chaye lishi ziliao xuanji [Selection of Historical Materials on Tea from Chinese Local Gazetteers]. Beijing: Nongye chuban she: Xinhua shudian Beijing faxing suo faxing, 1990.

\section{English Language Sources}

Antrobus, H. A. A History of the Assam Company, 1839-1953. Edinburgh: Private printing by T. and A. Constable, 1957.

Ball, Samuel. An Account of the Cultivation and Manufacture of Tea in China Derived from Personal Observation During an Official Residence in That Country from 1804 to 1826: And Illustrated by the Best Authorities, Chinese As Well As European: With Remarks on the Experiments Now Making for the Introduction of the Culture of the Tea Tree in Other Parts of the World. London: Printed for Longman, Brown, Green, and Longmans, 1848.

Barker, George M. A Tea Planter's Life in Assam. Calcutta: Thacker, Spink \& Co., 1884.

Barpujari, H. K., ed. The Comprehensive History of Assam: From the Prehistoric Times to the Twelfth Century A.D. Guwahati, Assam: Publication Board, 1990.

Bruce, C. A. An Account of the Manufacture of the Black Tea: As Now Practised at Suddeya in Upper Assam, by the Chinamen Sent Thither for That Purpose: With Some Observations on the Culture of the Plant in China, and Its Growth in Assam. Calcutta: G.H. Huttmann, 1838.

Chatterjee, Piya. A Time for Tea: Women, Labor, and Post/colonial Politics on an Indian Plantation. Durham: Duke University Press, 2001.

Cooke, Nola and Tana Li, ed. Water Frontier: Commerce and the Chinese in the Lower Mekong Region, 1750-1880. Singapore: Singapore University Press, 2004.

Fan, Fa-ti. British Naturalists in Qing China: Science, Empire, and Cultural Encounter. Cambridge, Mass: Harvard University Press, 2004.

Flynn, Dennis, and Arturo Giráldez. "Cycles of Silver: Global Economic Unity through the Mid-Eighteenth Century." Journal of World History 13, no. 2 (2002), 391-427.

Fortune, Robert. Three Years' Wanderings in the Northern Provinces of China: Including a Visit to the Tea, Silk and Cotton Countries. London: Kegan Paul, 2001.

- Two Visits to the Tea Countries of China and the British Tea Plantations in the Himalaya. London: J. Murray, 1853.

Gardella, Robert. Harvesting Mountains: Fujian and the China Tea Trade, 1757-1937. Berkeley: University of California Press, 1994.

Gates, Hill. China's Motor: A Thousand Years of Petty Capitalism. Ithaca, NY: Cornell University Press, 1996.

Ghosh, Kaushik. "A Market for Aboriginiality: Primitivism and Race Classification in the Indentured Labour Market of Colonial India." Subaltern Studies 10, no. 1 (1999), 8-48. 
Greenberg, Michael. British Trade and the Opening of China, 1800-42. Cambridge: University Press, 1951.

Griffiths, Percival Joseph. The History of the Indian Tea Industry. London: Weidenfeld \& Nicolson, 1967.

Guha, Amalendu. "Colonisation of Assam: Second Phase 18401859." Indian Economic \& Social History Review 4, no. 4 (1967), 289317.

- "Colonisation of Assam: Years of Transitional Crisis (1825-40)." Indian Economic \& Social History Review 5, no. 2 (1968), 125140.

- Planter-raj to Swaraj: Freedom Struggle and Electoral Politics in Assam, 1826-1947. New Delhi: Indian Council of Historical Research, 1977.

Harvey, David. The Limits to Capital. London: Verso, 1999.

. Spaces of Global Capitalism: Towards a Theory of Uneven Geographical Development. London: Verso, 2006.

Hevia, James Louis. English Lessons: The Pedagogy of Imperialism in Nineteenth-century China. Durham: Duke University Press, 2003.

Huang, H. T. Science and Civilisation in China. Volume 6: Biology and Biological Technology. Part V: Fermentations and Food Science. Joseph Needham: Science and Civilisation in China. Cambridge: Cambridge University Press, 2000.

Hobsbawm, E. J. Industry and Empire; an Economic History of Britain Since 1750. London: Weidenfeld \& Nicolson, 1968.

Karl, Rebecca. "The Burdens of History: Lin Zexu (1959) and The Opium War (1997)." In Whither China: Intellectual Politics in Contemporary China., edited by Zhang Xudong, 229-262. Durham: Duke University Press, 2001.

Kumar, Ravinder. Western India in the Nineteenth Century: A Study in the Social History of Maharashtra. London: Routledge \& K. Paul, 1968.

Lu, Weijing. "Beyond the Paradigm: Tea-picking Women in Imperial China." Journal of Women's History 15, no. 4 (2004), 19-46.

Ludden, David E, and Centre for Northeast India, South and Southeast Asia Studies. Where Is Assam?: Using Geographical History to Locate Current Social Realities. Guwahati: Centre for Northeast India, South and Southeast Asia Studies, Omeo Kumar Das Institute for Social Change and Development, 2003.

Marks, Robert. Tigers, Rice, Silk, and Silt: Environment and Economy in Late Imperial South China. Cambridge: Cambridge University Press, 1998.

Marx, Karl. Capital: Volume III, ed. Frederich Engels. New York: International Publishers, 1967. Marxists Internet Archive. http://marxists. org/archive/marx/works/1894-c3/ch48.htm

- "The East India Company - Its history and its results," New-York Herald Tribune, June 24, 1853. Marxists Internet Archive. http:// www.marxists.org/archive/marx/works/1853/07/11.htm

Mazumdar, Sucheta. Sugar and Society in China: Peasants, Technology, and the World Market. Cambridge, MA: Harvard University Asia Center, 1998.

. Sweetness and Power: The Place of Sugar in Modern History. New York: Viking, 1985.

- "Was the Plantation Slave a Proletarian?" Review: A Journal of the Fernand Braudel Center 2, no. 1 (1978), 81-98. 
Mui, Hoh-cheung and Lorna Mui. The Management of Monopoly: A Study of the English East India Company's Conduct of Its Tea Trade, 1784-1833. Vancouver, B.C: University of British Columbia Press, 1984.

Oxfeld, Ellen. Blood, Sweat, and Mahjong: Family and Enterprise in an Overseas Chinese Community. Ithaca, N.Y: Cornell University Press, 1993.

Reid, Anthony. "Chinese Trade and Southeast Asian Economic Expansion in the Later Eighteenth and Early Nineteenth Centuries: An Overview." In Water Frontier: Commerce and the Chinese in the Lower Mekong Region 1750-1880, ed. Nola Cooke and Li Tana, 21-34. Lanham, MD: Rowman \& Littlefield, 2004.

Richards, John. "The Opium Industry in British India." Indian Economic \& Social History Review 39, no. 2/3 (2002), 149-180.

Sen, Sudipta. Empire of Free Trade: The East India Company and the Making of the Colonial Marketplace. Philadelphia: University of Pennsylvania Press, 1998.

Sharma, Jayeeta. "British science, Chinese skill and Assam tea: Making empire's garden." Indian Economic \& Social History Review 43, no. 4 (2006), 429-455.

Singh, Navinder K. Role of Women Workers in the Tea Industry of North East India. New Delhi: Classical Pub. Co, 2001.

Stokes, Eric. The English Utilitarians and India. Oxford: Clarendon Press, 1959.

Trocki, Carl A. Opium, Empire and the Global Political Economy: A Study of the Asian Opium Trade. London: Routledge, 1999.

- "Chinese Capitalism and the British Empire," A paper presented to the International Association of Historians of Asia, Conference, Taipei, December 2004. http://eprints.qut.edu.au/archive/00000679/ 01/trocki_chinese.PDF

Xu Dixin and Wu Zhengming, ed. Chinese Capitalism, 1522-1840. Translated by Li Zhengde, Liang Miaoru, Li Siping. New York: St. Martin's Press, 2000. 